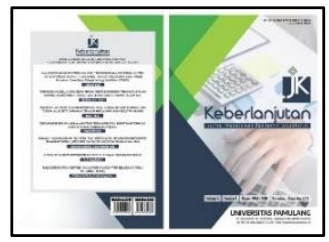

Keberlanjutan : Jurnal Manajemen dan Jurnal Akuntansi

http://openjournal.unpam.ac.id/index.php/keberlanjutan/index Volume 5 (1) 2020, 24-37

\title{
Pengaruh Lingkungan Kerja dan Budaya Kerja Islam Terhadap Kinerja Karyawan PT AJS Amanahjiwa Giri Artha
}

\section{Lukman Anthoni', Rahman Faisal2}

1 Universitas Pamulang, Indonesia

2 Universitas Pamulang, Indonesia

\section{Article Info}

Article history:

Received: 2020-04-30;

Accepted: 2020-06-17;

Published:2020-07-15.

Kata Kunci: Asuransi Syariah, Budaya Kerja, Kinerja Karyawan, Lingkungan Kerja

\begin{abstract}
In general, employee performance has several supporting factors to get maximum results. The work environment and work culture of Islam in companies that use Islamic principles have a role in carrying out operational activities. The results of this study aim to get a description of whether the work environment and Islamic work culture influence employee performance. Furthermore, the authors use quantitative methods with respondents representing Company employees who have filled out the research questionnaire documents as research instruments. Researchers also use the SPSS software application as a statistical calculation tool from data that has been collected to process research data. Hypothesis testing results between work environment $(X 1)$, Islamic work culture (X2) and employee performance (Y). In this study it was concluded (1) the work environment had a significant positive effect on employee performance, (2) the Islamic work culture had a significant positive effect on employee performance, (3) the work environment and Islamic work culture simultaneously had a significant positive effect on employee performance.
\end{abstract}

Amanahjiwa Giri Artha. Keberlanjutan : Jurnal Manajemen dan Jurnal Akuntansi, 5 (1), 24-37

Secara umum kinerja karyawan memiliki beberapa faktor pendukung agar mendapatkan hasil maksimal. Lingkungan kerja dan budaya kerja bertujuan untuk mendapatkan deskripsi apakah lingkungan kerja serta responden merupakan karyawan Perusahaan yang telah mengi dokumen kuesioner penelitian sebagai instrumen penelitian. Peneliti juga menggunakan aplikasi software SPSS sebagai alat bantu perhitungan statitstik dari data yang telah dikumpulkan untuk mengolah data penelitian. Hasil pengujian hipotesis antara lingkungan kerja (X1), budaya kerja Islam (X2) serta kinerja karyawan (Y). Dalam mempunyai pengaruh positif signifikan terhadap kinerja karyawan, (3) lingkungan kerja serta budaya kerja Islam secara bersamaan memiliki pengaruh yang positif signifikan terhadap kinerja karyawan. 


\section{PENDAHULUAN}

Karyawan yang professional, bertanggung jawab dan jujur merupakan suatu keharusan, hal tersebut dapat diusahakan melalui pembinaan atau pelatihan yang berkelanjutan dilakukan bagian SDM untuk berbagai jenjang jabatan. Urgensi kinerja karyawan sebagai salah satu faktor yang mendukung posisi perusahaan setiap periode dapat menjadi target bagian SDM untuk selalu di upgrade dengan adanya pelatihan, seminar dan sertifikasi profesi berbagai bidang. Beberapa aspek penilaian perusahaan asuransi jiwa syariah dapat dilihat dari laporan keuangan. Pencapaian kontribusi bruto per tahun perusahaan yang cenderung stagnan meskipun terjadi fluktuasi namun belum mempengaruhi pertumbuhan perusahaan. Laporan keungan perusahaan memperlihatkan kondisi yang belum memperoleh keuntungan sejak tahun kedua operasional perusahaan.

Karyawan sebagai sumber daya berjalannya perusahaan memiliki peran penting atas keberlangsungan dan suksesnya kinerja perusahaan. Berbagai faktor yang mempengaruhi kinerja karyawan dapat diasumsikan berdampak pada hasil kerja perusahaan. Sesuai dari hasil produksi polis individu maupun kumpulan perusahaan selama 6 (enam) tahun terakhir sejak perusahaan berdiri terjadi penurunan yang sangat signifikan, terutama polis asuransi jiwa individu. Berbagai persoalan system dan pemasaran terjadi yang diindikasikan terdapat faktor yang mempengaruhinya termasuk diantaranya lingkungan kerja serta budaya kerja. Perusahaan yang bergerak dengan konsep syariah semestinya menerapkan budaya kerja yang sesuai dengan syariat. Sehingga dapat menjadi ciri khas tersendiri dibandingkan perusahaan konvensional sejenis.

Karyawan yang bekerja dengan konsep syariah haruslah berlandaskan dari syariat Islam agar setiap pekerjaan dan hasil yang diperoleh bermanfaat dunia akhirat. Hasil kinerja karyawan sebagai bagian pencapaian kinerja perusahaan adalah penerbitan polis perusahaan baik untuk produk asuranis jiwa individu maupun produk asuransi jiwa kumpulan yang dipasarkan perusahaan. Pencapaian kinerja karyawan berbeda antara karyawan di bagian/divisi satu dengan yang lain. Produksi polis terkait dengan adanya pengajuan Surat Pengajuan Asuransi Jiwa (SPAJ) dari bagian/divisi marketing yang diterima dari pemegang polis. Proses produksi penerbitan polis sendiri terkait dengan Standard Operational Procedure (SOP) terkait bagian/divisi marketing, layanan pemasaran dan operasional. Sedangkan hasil kinerja perusahaan untuk bagian/divisi lainnya tidak terlepas dari jobdesk masing-masing bagian/divisi tersebut, misalkan kinerja investasi, kinerja keuangan serta sumber daya manusia.

Lingkungan kerja yang sehat mengakibatkan karyawan menjadi lebih stress, tidak bersemangat, sering terlambat, demikian jika semangat dalam bekerja akan dengan sendirinya muncul dari lingkungan kerja yang sehat sehingga dapat berkonsentrasi juga pekerjaan bisa selesai berdasarkan dengan tujuan yang telah di tentukan. Beberapa faktor dapat mempengaruhi keadaan lingkungan kerja, lokasi, akses untuk menjangkau tempat kerja, fasilitas dan sebagainya. Beberapa pengembangan dengan target peningkatan kinerja karyawan telah dilakukan terkait sarana prasarana dan sumber daya yang dimiliki perusahaan. Permasalahan yang terjadi didalam peningkatkan kinerja karyawan adalah bagaimana cara menerapkan lingkungan kerja yang baik serta budaya kerja Islam dalam menjalankan suatu pekerjaan. Secara umum, karena karyawan sehari-hari dalam bekerja tinggal atau bertempat pada kantor atau lingkungan kerjanya maka akan menjadi lebih optimal apabila lingkungan tempat karyawan bekerja dalam kondisi baik dan nyaman untuk melaksanakan tugas dan kewajibannya.

Kinerja pegawai adalah salah satu faktor yang memegang peranan penting dalam mencapai tujuan perusahaan maupun tujuan individu. Perusahaan akan mendapatkankesulitan mencapai tujuannya jika para karyawan di perusahaan tersebut tidak memiliki kinerja yang baik. Dalam usahanya untuk mencapai suatu tujuan perusahaan diperlukan adanya karyawan yang penuh kesadaran, kesetiaan, ketaatan, disiplin dan bertanggung jawab atas segala pekerjaan yang diberikan dan telah dikerjakan.

Berangkat dari latar belakang hasil penelitian di atas, menarik untuk melihat fenomena tersebut untuk dikaji bagaimana kinerja karyawan perusahaan dapat dilihat dalam penyelesaian proses pekerjaan masing-masing Divisi/ Departemen/ Unit Kerja yang dilakukan sesuai ketentuan dari masing-masing jobdesk yang telah diberikan perusahaan. 
Proses akseptasi Peserta atau Pihak Yang Diasuransikan dan Penerbitan Polis yang dilakukan Departemen Underwriting \& Reasuransi memiliki jangka waktu tersendiri dengan Departemen lain, misalkan dengan Departemen Service Polis \& Claim. Berdasarkan dengan uraian penjelasna sebelumnya, selanjutnya penulis berkeinginan menentukan penelitian mengenai "Pengaruh Lingkungan Kerja dan Budaya Kerja Islam Terhadap Kinerja Karyawan Pada PT Asuransi Jiwa Syariah Amanahjiwa Giri Artha". Kemudian menentukan rumusan penelitian yaitu (1) apakah lingkungan kerja sebagai variabel $X 1$ mempunyai pengaruh positif signifikan kepada varibel $Y$ yang ditentukan kinerja karyawan? (2) apakah variabel $X 2$ yaitu budaya kerja Islam mempunyai pengaruh positif signifikan kepada variabel $Y$ yang ditetapkan yaitu kinerja karyawan?, yang terakhir (3) apakah lingkungan kerja sebagai variable $\mathrm{X} 1$ dan budaya kerja Islam sebagia variabel $\mathrm{X} 2$ secara bersamaan mempunyai pengaruh positif signifikan kepada variabel $Y$ yang ditentukan sebagai kinerja karyawan.

Berdasarkan hasil produksi Polis Individu beberapa tahun terakhir terdapat penurunan sehingga diindikasikan terjadi penurunan kinerja karyawan sesuai dengan data yang ditunjukkan perusahaan terdapat tren penurunan produksi Polis Individu perusahaan. Dalam hal ini diindikasikan terdapat penurunan kinerja perusahaan yang dapat indikasikan terjadi karena beberapa faktor salah satunya kinerja karyawan. Hal ini juga telah dimunculkan manajemen perusahaan untuk dapat mencari beberapa faktor yang mempengaruhi kinerja karyawan tersebut sehingga nantinya dapat mempengaruhi kinerja perusahaan secara umum.

Untuk lebih menguatkan peneliti dalam melakukan penelitian lebih lanjut, bagaimana budaya kerja Islam memiliki pengaruh terhadap kinerja karyawan. Hasil penelitian tersebut mengindikasikan bahwa etos kerja islam memiliki pengaruh terhadap kinerja karyawan sehingga dengan adanya budaya kerja Islam adalah akhlak atau adab dalam bekerja sesuai dengan nilai-nilai yang diajarkan oleh Islam sehingga dalam melaksanakan pekerjaannya akan bernilai ibadah serta menghendaki keridhaan Allah Subhanahu wata'ala. Lingkungan kerja serta budaya kerja Islam yang diterapkan didalam perusahaan mempunyai peranan yang sangat penting bagi peningkatan kinerja karyawan dikarenakan bahwa para karyawan berorientasi bahwa kerja adalah suatu ibadah. Karyawan juga menjadikan lingkungan kerja sebagai rumah kedua mereka dan budaya kerja dalam ajaran Islam sebagai dasar aturan dalam bekerja serta menjadikannya contoh yang konkrit guna meningkatkan kinerja karyawan serta membuat sebuah kebijakan yang berpihak kepada karyawan serta sesuai dengan hukum dan syariat Islam sehingga dapat meningkatkan kinerja karyawan tersebut.

Berangkat dari latar belakang hasil penelitian di atas, menarik untuk melihat fenomena tersebut untuk dikaji bagaimana kinerja karyawan dapat dilihat dalam penyelesaian proses pekerjaan masing-masing jobdesk sesuai dengan SLA (Service Level Agreement) yang telah ditetapkan perusahaan. Proses dan target kerja masing-masing individu dapat mengukur capaian kinerja karyawan apakah dalma pengerjaan rutin tersebut misalnya apakah ada yang tidak sesuai atau menyalahi ketentuan target kerja masing-masing. Berdasarkan dengan uraian masalah di atas, maka penulis akan melakukan penelitian dengan judul "Pengaruh Lingkungan Kerja dan Budaya Kerja Islam Terhadap Kinerja Karyawan Pada PT AJS Amanahjiwa Giri Artha".

\section{LANDASAN TEORITIS DAN PENGEMBANGAN HIPOTESIS Lingkungan Kerja}

Keadaan lingkungan pada kehidupan manusia dapat mempengaruhi berbagai keaadaan disekitarnya, oleh karena itu hubungan antara lingkungan dengan manusia sangatlah erat karena dalam menjalankan kehidupan dan pekerjaannya sehari-hari manusia tinggal dalam lingkungannya. Beradaptasi dengan keadaan atau lingkungannya harus dilakukan manusia agar dapat bertahan hidup dan terus mengembangkan kemampuannya serta meningkatkan kualitas hidupnya. Lingkungan kerja merupakan bagian dari unsur yang dirasakan karyawan dalam berkerja atau pada saat manusia menjalankan rutinitasnya mencari nafkah. Kondisi dan berbagai permasalahan dalam bekerja tidak akan terlepas dari pekerjaan dan hal-hal rutin yang dilakukan serta dialami oleh karyawan sebagai bagian dari rutinitas kehidupan lingkungannya. 
Sesuatu yang berada disekitar karyawan serta dapat mempengaruhi diri karyawan dalam menjalankan atau melaksanakan tugas yang diberikan kepadanya, hal ini disampaikan menurut Nitisemito (1992). Penjelasan lain mengenai lingkungan kerja disampaikan pula oleh Sedarmayanti (2001) lingkungan disekitar tempat manusia bekerja dengan metode, pengaturan kerja baik secara individu maupun kelompok menyangkut alat perkakas dan bahan lain yang dihadapi oleh pekerja atau manusia tersebut. Perusahaandapat memberikan lingkungan kerja yang diharapkan karyawan dapat memberikan dukungan serta mampu menyokong kegiatan bekerja secara rutin dengan baik dalam bentuk kenyamanan, keamanan serta rasa memiliki dan menjadi bagian dari lingkungan kerja tersebut. Dalam pemaparan Sedarmayanti (2001) mengenai dampak pada jangka waktu lama mengenai lingkungan kerja bagi karyawan.

Menurut Bambang (1991), salah satu faktor yang mempengaruhi lingkungan kerja adalah kinerja karyawan. Kinerja yang baik yang dilakukan seorang pegawai/karyawan akan diperoleh jika lingkungan kerjanya dapat mendukungnya untuk mencapai kinerja yang diinginkan. Begitupun sebaliknya, apabila lingkungan kerjanya kurang baik dan memadai maka hal tersebut tidak dapat mendukungnya secara optimal serta dapat mengakibatkan kejenuhan, menimbulkan rasa malas, lebih terasa cepat lelah yang menjadikan kinerja karyawan yang dihasilkan pun tidak maksimal. Berdasarkan pendapat dan pandangan yang telah disampaikan sebelumnya maka ditarik kesimpulan yaitu lingkungan kerja yang bersentuhan secara rutin dialami dan dirasakan pegawai/karyawan ditempat kerja yang termasuk kategori fisik dan non fisik, yang secara langsung maupun tidak langsung bisa mempengaruhi karyawan itu sendiri serta hasil pekerjaannya saat yang bersangkutan bekerja.

Jenis lingkungan kerja diantaranya terdapat 2 (dua) bagian, berdasarkan hasil penelitian Sedarmayanti (2001) dapat dijelaskan diantaranya (1) bentuk lingkungan kerja yang bisa mempengaruhi kinerja karyawan secara langsung maupun tidak langsung merupakan bentuk lingkungan kerja fisik. Untuk kategori lingkungan kerja ini secara fisik dijelaskan menjadi 2 kelompok/kategori diantaranya lingkungan kerja yang bersentuhan serta terkait langsung secara rutin dan konsisten dengan karyawan seperti meja, kursi, komputer, kamar mandi, bagian dalam maupun bagian luar kantor atau tempat kerja serta pusat ruang kerja secara keseluruhan dan lain sebagainya. Selain itu lingkungan umum atau lingkungan perantara bias disebut juga lingkungan kerja serta hal-hal yang dapat mempengaruhi kondisi dan keadaan manusia juga termasuk dalam kategori lingkungan ini, misalnya sirkulasi ventilasi udara, kelembaban udara, temperature, bau atau udara yang kurang baik, kebisingan lingkungan, getaran mekanik dari mesin atau peralatan, pencahayaan, warna serta lain sebagainya. Usaha untuk memperkecil atau mengurangi dampak lingkungan katagori fisik terhadap karyawan harus segera dilakukan dengan mempelajari perilaku manusia atau pun karyawan itu sendiri, baik mengenal atau mengetahui secara fisik maupun dengan tingkah lakunya, sehingga hal ini dapat menjadi acuan atau dasar pemikiran menyesuaikan lingkungan fisik yang sesuai dengan keinginan juga harapan para karyawan. Paling tidak mendekati harapan karyawan sehingga seperti yang telah dikemukakan sebelumnya bahwa berdasarkan penelitian sebelumnya.

Hubungan kerja antara karyawan serta interaksi dengan lingkungan sekitar dan komunikasi dengan atasan, bawahan serta segala level yang ada di perusahaan merupakan lingkungan kerja bukan fisik. Mendukung kerjasama yang baik antara tingkat atasan maupun setiap jenjang tingkatan level jabatan karyawan merupakan salah satu bagian usaha perusahaan yang mencerminkan praktek langsung menerapkan kenyamanan lingkungan kerja. Mencoba mewujudkan suasana kerja dengan komunikasi yang positif, kekeluargaan serta pengendalian diri antar karyawan harus diterapkan sebagai sebuah kondisi standar lingkungan kerja perusahaan, Nitisemito (2000). Lingkungan kerja non fisik merupakan sebuah faktor yan tidak bisa dikesampingkan ataupun diabaikan agar dapat tercipta lingkungan kerja yang positif dan baik guna mendukung proses kinerja perusahaan dimasa mendatang. Berdasarkan pernyataan Sedarmayanti (2011) memberikan penjelasan secara ringkas bahwa lingkungan kerja dikelompokan atau dikategorikan menjadi 2 bagian yaitu lingkungan kerja non fisik dan lingkungan kerja fisik yang dalam penelitian ini dijelaskan dalam variable $\mathrm{X} 1$. Baik lingkungan kerja non fisik dan lingkungan kerja fisik pada penelitian 
ini digunakan untuk mengetahui bagaimana variable $\mathrm{X} 1$ yaitu lingkungan kerja memiliki pengaruh terhadap kinerja karyawan. Dengan demikian dapat diketahui pengaruhnya.

Tabel 1. Dimensi dan Indikator Lingkungan Kerja

\begin{tabular}{|c|l|l|}
\hline No & \multicolumn{1}{|c|}{ Dimensi } & \multicolumn{1}{c|}{ Indikator } \\
\hline 1 & $\begin{array}{l}\text { Lingkungan Kerja } \\
\text { Kategori Fisik }\end{array}$ & Sarana dan Prasarana. \\
\hline 2 & $\begin{array}{l}\text { Lingkungan Kategori } \\
\text { Non Fisik }\end{array}$ & $\begin{array}{l}\text { Hubungan antar karyawan dan } \\
\text { atau atasannya dan juga bawahan }\end{array}$ \\
\hline
\end{tabular}

\section{Budaya Kerja Islam}

Budaya merupakan sebuah identitas yang dimiliki manusia. Cara hidup yang mempunyai standar atau norma dalam masyarakat yang berfikir, bertingkah laku, merasa serta bekerja untuk menjadi sejahtera, makmur juga berkehidupan yang lebih baik. Segala bentuk pemikiran, nilai dan juga simbol-simbol yang dapat mempengaruhi sikap, kepercayaan, perilaku serta juga kebiasaan individu atau masyarakat merupakan salah satu pemahaman dari budaya.

Budaya yang menyandarkan pada ketentuan serta ketetapan AI Quran dan As Sunnah merupakan dasar budaya Islam. Salah satu hal yang sangat berharga di dunia adalah waktu, semestinya harus dihargai, dimanfaatkan, dimaksimalkan serta tidak boleh diabaikan penggunaannya oleh manusia. Hal ini telah banyak dijelaskan oleh junjungan umat akhir zaman ini yaitu Nabi Muhammad Shallallahu 'alaihi wasallam. Generasi berikut setelah beliau, yang terus menjaga dan mempertahankan ajaran beliau pun selalu menjaga dan menerapkan pemahaman bahwa waktu merupakan kunci penyesalan atau tidaknya manusia sampai dunia akhirat kelak.

Pada umumnya pemahaman budaya sangatlah mempengaruhi kehidupan sebuah kelompok manusia atau masyarakat serta biasanya diterapkan turun temurun. Budaya kerja Islam yang berlandaskan segala ajaran perilaku dan perbuatan Nabi Muhammad Shallallahu 'alaihi wasallam yang diturunkan dan diterapkan sampai akhir zaman merupakan sebuah pemahaman bahwa bekerja jika telah diniatkan serta terus dan mempertahankan niat tersebut sampai pekerjaan tersebut selesai maka akan termasuk dan tergolong melakukan ibadah yang mendapatkan ganjaran pahala. Dalam perkembangannya budaya kerja Islam tetap pada pemahaman awal meskipun berbagai bentuk dan jenis pekerjaan yang berkembang serta dinamis dan juga banyak metode bekerja yang baru muncul dan tampil sepanjang zaman. Hal inilah yang menjadi prinsip dasar seorang muslim hidup dan bekerja dimana tempat, bentuk dan jenis pekerjaan yang ditekuninya.

Secara mendasar, Budaya Kerja Islam adalah budaya yang kembali pada semua sifat dimana diajarkan pembawa Islam ke dunia ini yaitu Nabi Muhammad Shallallahu 'alaihi wasallam dan diantaranya sifat beliau adalah Siddiq, Istiqamah, Fathanah, Amanah dan juga Tablig. Beliau adalah sebaik-baiknya manusia dan contoh manusia yang segala sifat dan perilakunya merupakan hal terbaik. Sekaligus merupakan seorang pekerja yang dapat menjadi dasar kehidupan manusia dalam bekerja. Penjelasan sifat tersebut dapat dijelaskan sebagai berikut: 
1. Siddiq, bermakna benar atau pun dapat berarti jujur yang menjadi nilai dasar adalah integritas untuk setiap individu, berkata selalu benar, tidak berbohong, dan memiliki pikiran yang jernih. Sesuai dengan Al Quran surat At Taubah (119): "Hai orang-orang yang beriman bertakwalah kepada Allah, dan hendaklah kamu bersama orang-orang yang benar".

2. Istiqomah dapat bermakna konsisten untuk terus dalam kebaikan, ditunjukkan dengan kesabaran juga keteguhan serta keuletan dalam menjalankan aktivitas bekerja, sehingga menghasilkan suatu kinerja yang lebih optimal. Istiqamah adalah hasil yang didapatkan dari sebuah proses yang telah dikerjakan berkesinambungan atau berkelanjutan. Mempertahankan sifat istiqomah merupakan hal yang harus dilakukan untuk menjaga kebaikan agar dapat terus dilaksanakan sampai akhir hayat manusia. Doa merupakan senjata kaum muslimin untuk berbagai masalah dan kendala yang dihadapi, karena juga dengan berdoa, istiqomah dapat dilakukan untuk menjaga hubungan yang dekat dan erat kepada Sang Pencipta yaitu Allah S.W.T.

3. Fathanah dalam arti mempunyai pengetahuan luas, cepat tanggap, terampil juga mempunyai strategi yang tepat. Surat Yusuf ayat 55 yang artinya: "Jadikanlah aku bendaharawan negara (Mesir); sesungguhnya aku adalah orang yang pandai menjaga, lagi berpengetahuan".

4. Amanah memiliki makna mempunyai tanggung jawab untuk menjalankan kewajiban yang diberikan diberbagai waktu dan kesempatan. Wujud dari amanah dapat ditunjukkan serta dibuktikan dengan keterbukaan, pelayanan yang semaksimal mungkin, kejujuran dalam menjalankan tugas serta bersikap baik dalam kehidupan dan kegiatan sehari-hari. Dalam surat An Nisa ayat 58: "Sesungguhnya Allah menyuruh kamu menyampaikan amanat kepada yang berhak menerimanya, dan (menyuruh kamu) apabila menetapkan hukum diantara manusia supaya kamu menerapkan dengan adil. Sesungguhnya Allah memberi pengajaran yang sebaik-baiknya kepadamu Sesungguhnya Allah Maha Mendengar lagi Maha Melihat."

5. Tabligh, yang pada pelaksanaan berarti mampu berkomunikasi secara baik dengan berbagai unsur dan elemen di lingkungannya. Hal ini dapat ditunjukkan dengan kecerdasan, mudah bergaul, dapat mendeskripsikan tugas serta pendelegasian wewenang, bias bekerjasama dalam tim atau kelompok, dapat berkoordinasi dengan baik, memahami fungsi control serta mampu cepat tanggap terhadap keadaan yang berubah-ubah yang semakin cepat. Sesuai penjelasan dalam Al Quran surat Thaaha ayat 44 artinya: "Maka berbicaralah kamu berdua kepadanya dengan kata-kata yang lemah lembut, mudah-mudahan ia ingat atau takut." Instrumen budaya kerja islam meliputi:

Tabel 2. Dimensi dan Indikator Budaya Kerja Islam

\begin{tabular}{cll}
\hline No & \multicolumn{1}{c}{ Dimensi } & \multicolumn{1}{c}{ Indikator } \\
\hline 1 & Istiqomah & Tugas dan kewajiban karyawan. \\
2 & Fathonah, Tabligh & Pengetahuan terhadap pekerjaan. \\
3 & Siddiq, Amanah & Sikap dan tanggung jawab. \\
\hline
\end{tabular}

\section{Kinerja Karyawan}

Menjadi salah satu bagian penting perusahaan dapat mewujudkan tujuannya adalah dari kinerja karyawan. Seorang karyawan dalam setiap pelaksanaan tugasnya harus bertanggung jawab dari pekerjaan yang diberikan dengan indikasi hasil kerja yang dilihat dan dianalisis dari kualitas dan kuantitas kerja yang telah dicapainya sesuai arahan dan wewenang yang telah diberikan. Sesuatu hal yang telah dicapai, prestasi kerja yang telah dan dapat diperlihatkan atau ditunjukkan serta kemampuannya dalam bekerja merupakan penjelasan sesuai dengan Kamus Besar Bahasa Indonesia. Melakukan kegiatan juga menyempurnakannya berdasarkan tanggung jawab dan hsil yang diinginkan dari kesediaan seorang atau sekelompok orang yang melaksanakannya merupakan kinerja, Hannay (2010). Berdasarkan Wibowo (2009) dalam penelitian Arif serta Kartika (2012) memaparkan bahwa 
standar yang telah ditentukan dan ditetapkan dibandingkan dengan hasil kerja yang sudah didapatkan atau dilakukan pegawai/karyawan merupakan pemahaman kinerja, berdasarkan peran juga tugas yang telah dibebankan kepadanya.

Sedangkan menurut Sinambela (2012) menyatakan secara sudut pandang yang dilihat dari individu, pencapaian kinerja yang telah dicapainya memerlukan alat pengukuran pencapaian yang disebut kinerja.Tujuan dari didirikannya perusahaan adalah untuk mencapai visi dan misi perusahaan, baik secara komersial maupun non komersial. Pada akhirnya kinerja kpegawai/karyawan bisa mempengaruhi kinerja perusahaan karena karyawan adalah bagian dari sumber daya dan digunakan perusahaan dalam mencapai tujuan dan target yang sudah ditentukan. Diperlukan indikator untuk mengukur kinerja yang telah dicapai diantaranya kuantitas, kualitas, ketepatan waktu, efektifitas, kemandirian serta komitmen kerja untuk mendapatkan kinerja baik segala pihak sesuai tanggung jawab dan wewenang yang diterima perusahaan.

Tabel 3. Dimensi dan Indikator Kinerja Karyawan

\begin{tabular}{cll}
\hline No & \multicolumn{1}{c}{ Dimensi } & \multicolumn{1}{c}{ Indikator } \\
\hline 1 & Kualitas, Kuantitas & Hasil kerja karyawan dan peningkatan kinerja \\
2 & Waktu, Efektivitas, Kemandirian & Penggunaan waktu saat bekerja \\
3 & Komitmen kerja. & Kesetiaan karyawan terhadap perusahaan \\
\hline
\end{tabular}

Menurut (Alfajriani, 2017) hasil uji parsial dengan uji t mengenai pengaruh budaya kerja terhada kinerja karyawan tidak berpengaruh, sedangkan antara kompensasi terhadap kinerja karyawan memiliki pengaruh. Selain itu pula berdasarkan uji simultan penelitiannya tersebut dengan uji $f$ terdapat pengaruh antara budaya kerja dan kompensasi terhadap kinerja karyawan. Menurut (Iman, 2018) bahwa dengan menggunakan uji f secara simultan penelitiannya antara variabel bebas dan variabel terikat mendapatkan pengaruh yang signifikan, sedangkan pada uji t secara parsial mennunjukkan pengaruh yang positif dan signifikan untuk variabel bebas motivasi kerja dan budaya kerja Islam terhadap produktivitas kerja pada objek penelitiannya. Menurut (Prasetyowati, 2011) dalam penelitiannya bahwa beberapa variabel bebas yang ditentukan yaitu disiplin, lingkungan kerja, budaya kerja, motivasi dan kepemimpinan memiliki pengaruh yang signifikan terhadap variabel terikat yaitu kinerja karyawan. Tetapi berdasarkan (Hakim \& Suhendar, 2019), budaya organisasi tidak berpengaruh terhadap kinerja.

Berdasarkan penelitian (Sari, 2017) dari variabel bebas yang ditentukan peneliti terdapat variabel yang berpengaruh serta tidak berpengaruh terhadap variabel terikat. Namun dalam penelitian tersebut tidak diinformasikan dalam abstraksi terkait pengaruh positif atau negatif. Variabel etika kerja Islam dan motivasi kerja Islam tidak berpengaruh terhadap kinerja karyawan, sedangkan lingkungan kerja Islam berpengaruh terhadap kinerja karyawan. Sesuai dengan hasil penelitian (Iqram \& Rizal, 2019) menerangkan bahwa lingkungan kerja tidak berpengaruh secara signnifikan terhadap kinerja karyawan.

Hasil penelitian (Arianto, 2013) menjelaskan bahwa lingkungan kerja tidak berpengaruh terhadap kinerja karyawan, budaya kerja berpengaruh positif terhadap kinerja karyawan namun tidak dijelaskan signifikansi dari hasil penelitian tersebut. (Layaman \& Jumalia, 2016) mendapatkan hasil pada objek penelitiannya dengan menggunakan metode field research bahwa hasil penelitian yang didapatkan adalah budaya kerja dan etos kerja Islam berpengaruh terhadap kinerja karyawan namun tidak dijelaskan signifikansinya.

Pada hasil penelitiannya (Sakban et al., 2019) menerangkan bahwa objek penelitiannya telah melaksanakan, merencanakan, merekrut professional yang ahli dibidangnya serta mampu memberikan penghargaan juga memberikan hukuman apabila ada yang melanggar kode etik. Hal itu merupakan ahsil dari penelitian manajemen sumber daya manusia yang telah dilakukannya. Koentjaranigrat (2001) dalam (Busro, 2018) menjelaskan bahwa budaya dapat diartikan semua sistem, gagasan dan rasa, tindakan serta karya yang dihasilkan manusia dalam kehidupannya yang dijasikan dan dianggap sebagai miliknya melalui proses belajar. Selain itu, menurut Soekanto (2005) dalam buku (Busro, 2018) yang 
sama mendefinikan bahwa seorang pendukung budaya yang menganut suatu sistem nilai yang mencakup konsepsi abstrak baik dan buruk, benar atau salah. Atau, suatu suatu istitusi nilai yang dianut oleh suatu organisasi dari pelaksanaan adopsi yang didapat dari organisasi lain.

Uji hipotesis adalah uji sebuah taksiran yang dirumuskan dan diterima sementara untuk menerangkan fakta-fakta yang sedang diamati dan digunakan untuk proses selanjutnya. Berdasarkan rancangan analisis yang telah dikemukakan di atas, maka hipotesis untuk menggambarkan tingkat pengaruh antar variabel yang dibangun dalam penelitian ini adalah sebagai berikut:

1. Diduga terdapat pengaruh antara lingkungan kerja dengan kinerja karyawan.

2. Diduga terdapat pengaruh antara budaya kerja Islam dengan kinerja karyawan.

3. Lingkungan kerja dan budaya kerja Islam diduga secara bersama-sama berpengaruh terhadap kinerja karyawan.

Selain itu dapat pula dijelaskan dengan hipotesis statistik sebagai berikut:

Hipotesis statistik pertama (pengujian pengaruh $\mathrm{X} 1$ terhadap $\mathrm{Y}$ )

$\mathrm{H} 0: \beta 1=0$ tidak terdapat pengaruh $X 1$ terhadap $Y$

$\mathrm{Ha}: \beta 1 \neq 0$ terdapat pengaruh $\mathrm{X} 1$ terhadap $\mathrm{Y}$

Hipotesis statistik kedua (pengujian pengaruh $\mathrm{X} 2$ terhadap $\mathrm{Y}$ )

$\mathrm{H} 0: \beta 2=0$ tidak terdapat pengaruh $\mathrm{X} 2$ terhadap $Y$

$\mathrm{Ha}: \beta 2 \neq 0$ terdapat pengaruh $\mathrm{X} 2$ terhadap $Y$

Hipotesis statistik ketiga (pengujian pengaruh $X 1$ dan $X 2$ terhadap $Y$ )

$\mathrm{HO}: \beta 1,2=0$ tidak terdapat pengaruh $\mathrm{X} 1$ dan $\mathrm{X} 2$ terhadap $\mathrm{Y}$

$\mathrm{Ha}: \beta 1,2 \neq 0$ terdapat pengaruh $\mathrm{X} 1$ dan $\mathrm{X} 2$ terhadap $Y$

Uji $\mathrm{T}$ digunakan untuk menentukan atau menyimpulkan hasil penelitian dengan menguji signifikan atau tidak. Uji $\mathrm{T}$ juga berfungsi untuk menguji hipotesis penelitian yang bersifat terpisah. Kriteria pengujiannya $\mathrm{HO}$ diterima jika $\mathrm{t}$ hitung $<\mathrm{t}$ tabel dan $\mathrm{HO}$ ditolak jika t hitung $>\mathrm{t}$ tabel.

Uji F digunakan untuk menguji hipotesis penelitian (simultan) yaitu ada atau tidaknya pengaruh seluruh variabel bebas terhadap variabel terikat secara bersama (Sugiyono: 2007). Pengujian dilakukan dengan menggunakan angka $F$ dari output ANOVA sebagai $\mathrm{F}$ hitung dengan kriteria jika $\mathrm{F}$ hitung $>\mathrm{F}$ tabel, maka $\mathrm{H} 0$ ditolak dan $\mathrm{Ha}$ diterima dan jika $\mathrm{F}$ hitung $<\mathrm{F}$ tabel, maka $\mathrm{HO}$ diterima dan $\mathrm{Ha}$ ditolak. Dengan menghitung $\mathrm{F}$ tabel menggunakan ketentuan $\alpha=0,05$

\section{METODE PENELITIAN}

Peneliti melakukan penelitian yang dilaksanakan 6 (enam) bulan periode tahun 2018/2019 dengan melakukan analisis dan pengamatan bagi karyawan/pegawai perusahaan dengan metode kuantitatif asosiatif dengan hasil dideskripsikan sesuai dengan temuan dan juga hasil penelitian. Cara yang dilakukan untuk mendukung metode penelitian ini yaitu dengan menyebarkan kuesioner kepada para karyawan sebagai responden penelitian. Penelitian dilakukan dengan mengumpulkan data sesuai dengan variable penelitian yang telah ditentukan yaitu variable $\mathrm{X} 1$ yaitu lingkungan kerja, budaya kerja Islam sebagai variable $\mathrm{X} 2$ serta kinerja karyawan sebagai variable $\mathrm{Y}$ dan untuk penelitian ini digunakan kuesioner (angket) dengan rincian total sebanyak 30 pertanyaan, yaitu 10 pertanyaan untuk budaya kerja islam, 10 pertanyaan untuk lingkungan kerja dan 10 pertanyaan lagi untuk kinerja karyawan yang diteliti. Peneliti juga menentukan kerangka berfikir sebagai berikut: 


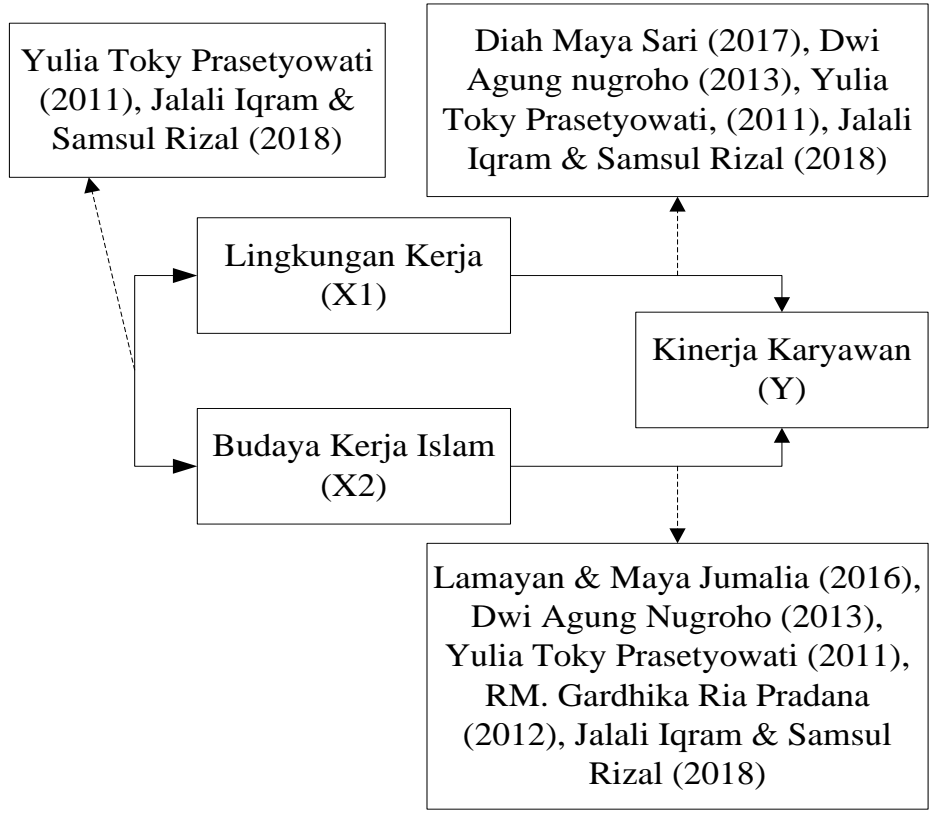

\section{Gambar 1. Kerangka Berfikir}

Hipotesis awal yang peneliti tentukan dari penelitian-penelitian sebelumnya dan pada penelitian ini adalah (1) lingkungan kerja sebagai variable $\mathrm{X} 1$ berpengaruh positif terhadap variable $Y$ yaitu kinerja karyawan, (2) variable $X 2$ yaitu budaya kerja Islam berpengaruh positif terhadap kinerja karyawan, dan terakhir (3) variable $\mathrm{X} 1$ dan variable $\mathrm{X} 2$ yaitu masingmasing lingkungan kerja dan budaya kerja Islam berpengaruh positif terhadap kinerja karyawan sebagai variable $Y$. Instrumen penelitian yang dipilih bertujuan dengan melakukan pengukuran untuk menghasilkan data kuantitatif yang akurat, maka instrumen yang digunakan adalah pemberian skor yang mengunakan teknik skala likert. Penggunaan instrumen penelitian yang berupa kuisioner, penulis menggunakan metode skala likert digunakan untuk mengetahui pengukuran jawaban responden. Dengan menggunakan skala likert maka variabel yang akan di ukur dan di jabarkan menjadi indicator variabel jawaban mempunyai gradisi dari sangat positif sampai sangat negatif.

Metode analisis data yang di gunakan untuk menganalisis data antara lain (1) Uji Validitas (2) Uji Reliabilitas. (3) Uji Normalitas. (4) Uji Autokorelasi. Menurut Imam Ghozali (2013: 110). Metode pengujian menggunakan uji Durbin-Watson (uji DW). (5) Koefisien Korelasi. Teknik koefisien korelasi yang berupa rumus statistik teknik korelasi tunggal untuk mencari koefisiensi korelasi antar data interval. (6) Koefisien Determinasi dan Simultan. Menurut Imam Ghozali (2009) koefisien determinasi bertujuan pada intinya mengukur seberapa jauh kemapuan sebuah model dalam menerangkan variasi variabel dependen. Untuk mengetahui sejauh mana hubungan antar variabel yang telah ditentukan sebelumnya dan kemudian dihitung menggunakan rumus uji koefisien determinasi sebagai berikut: $\mathrm{KD}=$ $r^{2} \times 100 \%$. (7) Analisis Regresi Berganda. Analisis regresi berganda bertujuan untuk megetahui ada atau tidaknya pengaruh signifikan dua atau lebih variabel bebas terhadap variabel terikat sesuai Danang Sunyoto (2011). Sugiyono (2014) menyatakan peneliti menentukan apa saja yang berbentuk apa pun untuk dipelajari agar mendapatkan informasi mengenai hal tersebut. Konsep dan operasional variabel penelitian:

Tabel 4. Operasional Variabel

\begin{tabular}{|c|c|c|c|}
\hline Variabel & Definisi & Indikator & Skala \\
\hline Lingkungan Kerja; & Lingkungan & Fisik & Likert \\
\hline $\begin{array}{c}\text { Sedarmayanti (2001), } \\
\text { Nitisemito (1992), } \\
\text { Bambang (1991) }\end{array}$ & $\begin{array}{l}\text { kehidupan sosial, fisik dalam } \\
\text { perusahaan serta psikologi yang } \\
\text { sangat berpengaruh terhadap } \\
\text { karyawan dalam menjalankan } \\
\text { serta melaksanakan tugasnya. }\end{array}$ & Non Fisik & \\
\hline
\end{tabular}




$\begin{array}{clll}\text { Budaya Kerja Islam; } & \text { Sesuai dengan ketentuan } & \text { Siddiq } & \text { Likert } \\ \text { Al-Quran dan Hadits } & \text { syariat berdasarkan Al Quran Istiqomah } & \\ & \begin{array}{l}\text { dan As Sunnah dalam } \\ \text { melaksanakan rutinitas "kerja" }\end{array} & \text { Amanah } \\ & \begin{array}{l}\text { atau "bekerja" } \\ \text { berlandaskan Islam. }\end{array} & \\ \text { Kinerja Karyawan; } & \text { Kemampuan berprestasi dalam } & \text { Kualitas } & \text { Likert } \\ \text { Hannay (2010), Arif \& } & \begin{array}{l}\text { kerja karyawan secara nyata } \\ \text { Kartika (2012), }\end{array} & \text { untuk memenuhitas standar kerja } & \text { Waktu } \\ \text { Sinambela (2012) } & \text { yang diterapkan. } & \begin{array}{l}\text { Efektivitas } \\ \text { Komitmen Kerja }\end{array}\end{array}$

Pada penelitian kali ini peneliti menentukan objek penelitian pada PT. AJS Amanahjiwa Giri Artha. Jakarta. Perusahaan ini bergerak dalam bidang asuransi jiwa syariah dimana di setiap kegiatannya selalu yang istiqomah dalam menggaungkan syariah dalam praktik bisnisnya. Variabel penelitian sesuai dengan pembatasan masalah objek yang diteliti adalah dari 3 variabel yaitu variabel $\mathrm{X} 1$ ditentukan sebagai lingkungan kerja, budaya kerja Islam ditetapkan menjadi variabel $\mathrm{X} 2$ dan variabel $\mathrm{Y}$ ditentukan kinerja karyawan. Cara pengumpulan data dapat dilakukan yaitu yang terdiri dari penggunaan kuesioner atau angket serta penggunaan metode kepustakaan (dokumentasi). Untuk dapat memperoleh pengukuran jawaban dari responden dengan menyebarkan kuesioner serta memakai skala likert.

Tabel 5. Skala Likert

\begin{tabular}{cc}
\hline Jawaban & Nilai \\
\hline Sangat Setuju (SS) & 5 \\
Setuju (S) & 4 \\
Ragu-ragu (R) & 3 \\
Tidak Setuju (TS) & 2 \\
Sangat Tidak Setuju (STS) & 1 \\
\hline Sumber: Sugiyono (2012) &
\end{tabular}

\section{HASIL PENELITIAN DAN PEMBAHASAN}

Karakteristik Responden (1) Karakteristik responden pria 44 orang dan wanita 11 orang. (2) Karakteristik responden sesuai usia: (1) < 20 tahun berjumlah 2 karyawan. (2) 21 - 30 tahun berjumlah 18 karyawan (3) 31 - 40 tahun sebanyak 22 orang (4) $40>$ tahun sebanyak 13 orang. (3) kelompok responden berdasarkan tingkat pendidikan yaitu lulusan S1 yang berjumlah 30 orang atau 54,5\%, sedangkan tingkat pendidikan paling sedikit adalah S2 dan SMA yaitu hanya 5 orang saja atau 9,1\% dari total pegawai yang ada. (4) kelompok responden berdasarkan lama bekerja di perusahaan di dominasi oleh pegawai/karyawan dengan lama bekerja 2 - 4 tahun dengan 35 orang atau $63,6 \%$, sedangkan lama bekerja paling sedikit didominasi dengan lama kerja 1 tahun yaitu sebanyak 8 orang atau 14,6\%.

Uji Validitas dan Reliabilitas. Nilai Cronbach Alpha digunakan untuk mendapatkan hasil uji reliabilitas. Dimana nilai Cronbach Alpha kemudian dibandingkan dengan rTabel menggunakan tingkat signifikansi 5\%. Apabila nilai Cronbach Alpha $>r_{\text {tabel }}$ maka dapt

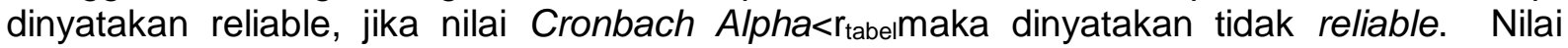
Cronbach Alpha Variabel Lingkungan Kerja (X1) lebih besar dibandingkan $r_{\text {tabel }}(0,913>$ $0,220)$ yang berarti menunjukan bahwa ke sepuluh pernyataan tersebut reliable. Nilai Cronbach Alpha Variabel Budaya Kerja Islam (X2) lebih besar dibandingkan $r_{\text {tabel }}(0,794>$ $0,220)$ yang berarti menunjukan bahwa ke sepuluh pernyataan tersebut reliable.

Nilai Cronbach Alpha variable $Y$ lebih besar dibandingkan $r_{\text {tabel }}(0,541>0,220)$ yang berarti menunjukan bahwa ke sepuluh pernyataan tersebut reliable.

Dalam pengujian uji autokorelasi, peneliti menggunakan uji Durblin Watsonuntuk menguji ada atau tidaknya autokorelasi diantara variable X1, X2 dan $\mathrm{Y}$ yang dapat dilihat dalam table model summary berikut ini: 
Tabel 6

Model Summaryb

\begin{tabular}{|c|c|c|c|c|c|c|c|c|c|c|}
\hline \multirow[t]{2}{*}{ Model } & \multirow[t]{2}{*}{$\mathrm{R}$} & \multirow{2}{*}{$\begin{array}{c}R \\
\text { Square }\end{array}$} & \multirow{2}{*}{$\begin{array}{l}\text { Adjusted } \\
\text { R Square }\end{array}$} & \multirow{2}{*}{$\begin{array}{l}\text { Std. Error } \\
\text { of the } \\
\text { Estimate }\end{array}$} & \multicolumn{5}{|c|}{ Change Statistics } & \multirow{2}{*}{$\begin{array}{l}\text { Durbin- } \\
\text { Watson }\end{array}$} \\
\hline & & & & & $\begin{array}{c}\mathrm{R} \\
\text { Square } \\
\text { Change }\end{array}$ & $\begin{array}{c}\mathrm{F} \\
\text { Change }\end{array}$ & df1 & $\mathrm{df2}$ & $\begin{array}{c}\text { Sig. F } \\
\text { Change }\end{array}$ & \\
\hline 1 & $.796^{\mathrm{a}}$ & .634 & .620 & 2.592 & .634 & 44.972 & 2 & 52 & .000 & 1.095 \\
\hline
\end{tabular}

a. Predictors: (Constant), Budaya Kerja Islam, Lingkungan Kerja

b. Dependent Variable: Kinerja Karyawan

Sumber: SPSS versi 20.0

Sesuai dengan hasil uji autokorelasi nilai dari uji diatas didapatkan nilai Durbin-Watson sebesar 1.095 artinya nilai itu masih diantara -2 sampai 2 yang artinya tidak terjadi autokorelasi.

Tabel 7

Coefficients $^{\mathrm{a}}$

\begin{tabular}{|c|c|c|c|c|c|c|c|c|}
\hline \multirow{2}{*}{\multicolumn{2}{|c|}{ Model }} & \multicolumn{2}{|c|}{$\begin{array}{c}\text { Unstandardized } \\
\text { Coefficients }\end{array}$} & \multirow{2}{*}{$\begin{array}{c}\text { Standardized } \\
\text { Coefficients } \\
\text { Beta }\end{array}$} & \multirow[t]{2}{*}{$\mathrm{T}$} & \multirow[t]{2}{*}{ Sig. } & \multicolumn{2}{|c|}{ Collinearity Statistics } \\
\hline & & B & $\begin{array}{l}\text { Std. } \\
\text { Error }\end{array}$ & & & & Tolerance & VIF \\
\hline \multirow{3}{*}{1} & (Constant) & 6.719 & 3.398 & & 1.978 & .053 & & \\
\hline & Lingkungan Kerja & .168 & .118 & .204 & 1.429 & .159 & .347 & 2.882 \\
\hline & Budaya Kerja Islam & .652 & .149 & .622 & 4.368 & .000 & .347 & 2.882 \\
\hline
\end{tabular}

a. Dependent Variable: Kinerja_Karyawan

Pada uji multikolineritas koefisien Varian Inflation (VIF) variabel independent Lingkungan Kerja (X1) sebesar 2.882, Budaya Kerja Islam (X2) sebesar 2.882.

Korelasi lingkungan kerja sebagai variable (X1 dengan kinerja karyawan sebagai variable $(\mathrm{Y})$

Tabel 8

\begin{tabular}{|ll|r|r|}
\hline \multicolumn{2}{|c|}{ Correlations } \\
\hline \multirow{2}{*}{ Pearson Correlation } & Kinerja Karyawan & Lingkungan Kerja \\
& Kinerja Karyawan & 1.000 & .707 \\
& Lingkungan Kerja & .707 & 1.000 \\
Sig. (1-tailed) & Kinerja Karyawan &. & .000 \\
& Lingkungan Kerja & 50 &. \\
$\mathrm{~N}$ & Kinerja Karyawan & 55 & 55 \\
& Lingkungan Kerja & 55 \\
\hline
\end{tabular}

Variabel $\mathrm{X} 1$ dan $\mathrm{Y}(\mathrm{R}=0.707$; Sig $=0.000)$ dan hubungan bersifat positif atau searah dengan nilai signifikansinya $<0.05$.

Koefisien Determinasi Lingkungan Kerja sebagai Variabel (X1) dengan Kinerja Karyawan sebagai Variabel $(Y)$ menunjukkan bahwa nilai koefisien korelasi $(R)$ disimpulkan untuk variable dependent atau variable $(\mathrm{Y})$ bisa dijelaskan oleh variable independent atau variable X1 sebesar 49,9\%, selanjutnya untuk lainnya dipengaruhi variabel lain.

Regresi variabel $X 1$ dengan variabel $Y$

Persamaan regresi linier variable $X 1$ yaitu lingkungan kerja dan variable $Y$ yaitu kinerja 
karyawan; $\mathrm{Y}=\beta 0+\beta 1 \mathrm{X}_{1}+\varepsilon ; \mathrm{Y}=15.380+0.584 \mathrm{X}_{1}+\varepsilon ;$ Apabila Lingkungan Kerja $\left(\mathrm{X}_{1}\right)$ dinaikkan 1.000 satuan maka terjadi perubahan Kinerja Karyawan sebesar 0.584 . Berdasarkan nilai t hitung untuk koefisien X1 adalah sebesar 7.269 dengan nilai sig. 0,000.

Korelasi Antara Budaya Kerja Islam sebagai variabel (X2) dengan Kinerja Karyawan sebagai variabel $(Y)$

Tabel 9

Correlations

\begin{tabular}{|ll|r|r|}
\hline & & \multicolumn{1}{|c|}{$\begin{array}{c}\text { Kinerja } \\
\text { Karyawan }\end{array}$} & $\begin{array}{c}\text { Budaya Kerja } \\
\text { Islam }\end{array}$ \\
\hline Pearson Correlation & Kinerja Karyawan & 1.000 & .787 \\
& Budaya Kerja Islam & .787 & 1.000 \\
Sig. (1-tailed) & Kinerja Karyawan &. & .000 \\
& Budaya Kerja Islam & .000 &. \\
N & Kinerja Karyawan & 55 & 55 \\
& Budaya Kerja Islam & 55 & 55 \\
\hline
\end{tabular}

Variabel $X_{2}$ dan $Y(R=0.787 ;$ Sig $=0.000)$ dan hubungannya bersifat positif atau searah dengan nilai signifikansinya $<0.05$.

Koefisien Determinasi Budaya Kerja Islam sebagai variabel (X2) dengan Kinerja Karyawan sebagai variabel (Y) menunjukkan bahwa nilai koefisien korelasi $(\mathrm{R})$ antara variabel independent Budaya Kerja Islam (X2) dan kinerja Karyawan (Y) didapatkan sebesar 0.787, serta koefisien determinasi ( $R$ Square) 0.619.

Regresi linier Budaya Kerja Islam ( $\left.X_{2}\right)$ dan Kinerja Karyawan $(Y) ; Y=\beta 0+\beta 2 X 2+\varepsilon ; Y=$ $6.733+0.824 \mathrm{X}_{2}+\varepsilon$; didapat nilai t hitung untuk koefisien $\mathrm{X}_{2}$ yaitu sebesar 9.285 dengan nilai sig. 0.000 sesuai penjelasan $t$ hitung $(9.285)>t$ tabel $(0,05,54)(1,673)$ Maka $\mathrm{H}_{1}$ (X2) ditolak dan terima $\mathrm{H}_{0}\left(\mathrm{X}_{2}\right)$. Nilai Sig $(0,000)>0,05 \mathrm{Maka}_{1}\left(\mathrm{X}_{2}\right)$ ditolak dan terima $\mathrm{H}_{0}\left(\mathrm{X}_{2}\right)$. Artinya, koefisien variabel Budaya Kerja Islam ( $\left.\mathrm{X}_{2}\right)$ secara parsial tidak signifikan mempengaruhi variabel Kinerja Karyawan (Y).

Korelasi antara lingkungan kerja sebagai variabel $\mathrm{X} 1$, budaya kerja Islam sebagai variabel $\mathrm{X} 2$ dengan kinerja karyawan sebagai variabel $\mathrm{Y}$.

Tabel 10

Correlations

\begin{tabular}{|ll|r|r|r|}
\hline & & Kinerja Karyawan & Lingkungan Kerja & Budaya Kerja Islam \\
\hline \multirow{2}{*}{ Pearson } & Kinerja Karyawan & 1.000 & .707 & .787 \\
Correlation & Lingkungan Kerja & .707 & 1.000 & .808 \\
& Budaya Kerja Islam & .787 & .808 & 1.000 \\
& Kinerja Karyawan &. & .000 & .000 \\
Sig. (1-tailed) & Lingkungan Kerja & .000 &. & .000 \\
& Budaya Kerja Islam & .000 & .000 &. \\
& Kinerja Karyawan & 55 & 55 & 55 \\
$\mathrm{~N}$ & Lingkungan_Kerja & 55 & 55 & 55 \\
& Budaya_Kerja_Islam & 55 & 55 & 55 \\
\hline
\end{tabular}

Korelasi antara lingkungan kerja sebagai variabel $X 1$, budaya kerja Islam sebagai variabel $X 2$ dengan kinerja karyawan sebagai variabel $Y$ dijelaskan bahwa variabel $X$ dan $Y(R=$ X1: 0.707; X2: 0.787 dan Sig $=0.000$ dan 0.000). Selain itu terdapat hubungan yang signifikan antara lingkungan kerja sebagai variabel $\mathrm{X} 1$, budaya kerja Islam sebagai variabel $\mathrm{X} 2$ dengan kinerja karyawan sebagai variabel $\mathrm{Y}$, karena $<0.05$. 
Koefisien determinasi antara lingkungan kerja sebagai variabel $\mathrm{X} 1$, budaya kerja Islam sebagai variabel $\mathrm{X} 2$ dengan kinerja karyawan sebagai variabel $Y$ dapat dijelaskan bahwa koefisien korelasi $(R)$ antara variabel independent antara lingkungan kerja sebagai variabel $\mathrm{X} 1$, budaya kerja Islam sebagai variabel $\mathrm{X} 2$ dengan variabel dependent kinerja karyawan sebagai variabel $Y$ didapat sebesar 0.796 serta $R$ Square sebesar 0.634 .

Hubungan (ANOVA) lingkungan kerja (X1), budaya kerja islam (X2) dengan kinerja karyawan (Y)

\begin{tabular}{|rl|r|r|r|r|r|}
\hline \multicolumn{1}{|c|}{ ANOVA $^{\mathrm{a}}$} \\
\hline \multirow{2}{*}{1} & Sum of Squares & Df & Mean Square & \multicolumn{1}{c|}{$\mathrm{F}$} & \multicolumn{1}{c|}{ Sig. } \\
\hline & Regression & 604.120 & 2 & 302.060 & 44.972 & $.000^{\mathrm{b}}$ \\
& Residual & 349.261 & 52 & 6.717 & & \\
& Total & 953.382 & 54 & & & \\
\hline
\end{tabular}

a. Dependent Variable: Kinerja Karyawan

b. Predictors: (Constant), Budaya Kerja Islam, Lingkungan Kerja

Uji signifikansi persamaan regresi linier $\left(\mathrm{X}_{1}\right)$, (X2) terhadap $(\mathrm{Y})$ dilanjutkan dengan menghitung nilai $\mathrm{f}$. Hal ini dilakukan dan diperhitungkan untuk mengetahui seberapa besar kemampuan variabel independent lingkungan kerja X1 dan budaya kerja Islam X2 untuk memprediksi perubahan yang terjadi pada variabel dependent kinerja karyawan $(Y)$. sesuai dengan hasil yang didapatkan bahwa $f$ hitung (44.972) $>f$ tabel artinya $f$ hitung lebih besar daripada $f$ tabel. Tolak $H 0$ (X1, X2) sehingga $H 1$ (X1, X2) diterima (Signifikan) Nilai Sig. $(0,000)<0,05$. Tolak $H 0(X 1, X 2)$ sehingga $H 1(X 1, X 2)$ diterima (Signifikan). Selanjutnya hipotesis pada pnelitian ini yaitu $\mathrm{H} 1$ (X1, X2): diterima, lingkungan kerja $\mathrm{X} 1$ dan budaya kerja Islam $\mathrm{X} 2$ diduga berpengaruh dengan kinerja karyawan $\mathrm{Y}$ artinya variabel independent lingkungan kerja X1 dan Budaya Kerja Islam X2 secara simultan signifikan mempengaruhi variabel dependent kinerja karyawan $\mathrm{Y}$.

Tabel Rangkuman Hasil Pengujian Hipotesis Uji t

\begin{tabular}{cccccl}
\hline No & Pengaruh & Hipotesis & $\mathbf{t}$ & Sig & Keterangan \\
\hline 1 & X1 terhadap $Y$ & $\mathrm{H} 1$ & 7.269 & 0.707 & Ditolak \\
2 & X2 terhadap $Y$ & $\mathrm{H} 2$ & 9.285 & 0.787 & Ditolak \\
\hline
\end{tabular}

Sumber : data yang diolah

Tabel Rangkuman Hasil Pengujian Hipotesis Uji $f$

\begin{tabular}{cccccl}
\hline No & Pengaruh & Hipotesis & $\mathbf{f}$ & Sig & Keterangan \\
\hline 1 & $\mathrm{X} 1$ dan $\mathrm{X} 2$ terhadap $\mathrm{Y}$ & $\mathrm{H} 3$ & 44.972 .269 & 0.000 & Ditolak \\
\hline
\end{tabular}

\section{KESIMPULAN DAN SARAN}

Berdasarkan hasil penelitian dapat disimpulkan bahwa (1) lingkungan kerja sebagai variabel $\mathrm{X} 1$ berpengaruh positif dan signifikan terhadap kinerja karyawan sebagai variabel $Y$ (2) budaya kerja Islam sebagai variabel X2 berpengaruh positif dan signifikan terhadap kinerja karyawan sebagai variabel $Y(3)$ lingkungan kerja sebagai variabel $X 1$ dan budaya kerja Islam sebagai variabel $\mathrm{X} 2$ berpengaruh positif dan signifikan terhadap kinerja karyawan sebagai variabel $\mathrm{Y}$.

Selain itu peneliti dapat memberikan saran atau rekomendasi diantaranya (1) Lingkungan Kerja. Untuk itu, rekomendasi peneliti pada lingkungan kerja baiknya Perusahaan dapat meningkatkan dan memperhatikan kondisi lingkungan baik fisik dan non fisik. Sehingga karyawan dapat meningkatkan kinerja menjadi lebih baik lagi. Lingkungan yang dimaksud berupa kenyamanan dan keamaman selama bekerja. (2) Budaya Kerja 
Islam. Dari hasil penelitian budaya kerja islami tentunya sangat baik untuk dapat meningkatkan kinerja karyawan. Namun panutan disetiap bagian/departemen diperlukan oleh karyawan. Contoh rekomendasi kami misalnya, membuat pengajian rutin, membiasakan dan mencontohkan untuk tetap menjaga kebersihan.

Melakukan pekerjaan yang dapat dipercaya, bekerja dengan jujur tidak memanfaatkan waktu kerja untuk kepentingan pribadi bukan di jam kerja malah digunakan untuk keperluan lain yang tidak ada hubungan dengan perusahaan. Hal ini yang belum mencerminkan budaya islam. (3) Pengaruh yang positif dan signifikan antar variabel ini jika didalami lebih lanjut memang ada faktor lain yang mempengaruhinya. Untuk itu diperlukan kebijakan Perusahaan yang mendukung peningkatan kinerja karyawan dengan mengadaptasi budaya kerja islam. Selain kebijakan perusahaan, peran karyawan itu sendiri khususnya yang Muslim melakukan budaya-budaya islam dalam bekerja. Sehingga dengan penerapan budaya kerja yang sesuai dengan syariat Islam, diharapkan bisa meningkatkan produktifitas serta kinerja karyawan dan kinerja perusahaan dimasa yang akan datang.

Saran untuk penelitian selanjutnya agar variabel yang mempengaruhi kinerja karyawan dapat berkembang serta dapat dilakukan penelitian kembali dengan adanya kegiatan dan media kerja yang terus berkembangan dengan dukungan teknologi terkini. Pola kebiasaan kerja bagi pegawai/karyawan perusahaan saat ini mendorong adanya variabelvariabel baru yang dapat diteliti sebagai beberapa indikator tambahan terhadap penilaian kinerja karyawan. Cara kerja jarak jauh dengan cara online merupakan pola baru yang belum banyak dilakukan penelitian lebih lanjut dan ini dapat menjadi keilmuan yang dapat bermanfaat bagi perkembangan ilmu pengetahuan.

\section{DAFTAR PUSTAKA}

Alfajriani, R. N. (2017). Pengaruh Budaya Kerja dan Kompensasi Terhadap Kinerja Karyawan Pada PT Lestasi Mahaputra Buana Bandung. Repository Universitas Widyatama.

Arianto, D. A. N. (2013). Pengaruh Kedisiplinan, Lingkungan Kerja Dan Budaya Kerja Terhadap Kinerja Tenaga Pengajar. Jurnal Economia, 9(2), 191-200.

Busro, M. (2018). Teori-Teori Manajemen Sumber Daya Manusia. Kencana.

Hakim, D. R., \& Suhendar, D. (2019). Determinan Optimalisasi Kinerja Organisasi Dengan Modmed Variabel Analisis (Studi pada Dinas Pendidikan dan Kebudayaan Kabupaten Kuningan). Bisnet, 2(2), 23-34.

Iman, A. N. (2018). Pengaruh Motivasi Kerja Islam Dan Budaya Kerja Islam Terhadap Produktivitas Karyawan Baitul Mal Wa Tamwil (BMT) di Gerbangkertasusila (Gresik, Bangkalan, Mojokerto, Surabaya, Sidoarjo, Lamongan). Skripsi - Perpustakaan Universitas Airlangga.

Iqram, J., \& Rizal, S. (2019). Pengaruh Budaya Organisasi Dan Lingkungan Kerja Terhadap Kinerja Pegawai Pada Kantor Kecamatan Tanete Rilau Kab. Barru. Jurnal Profitability Fakultas Ekonomi Dan Bisnis, 3(1), 54-65.

Layaman, \& Jumalia, M. (2016). Pengaruh Budaya Kerja Dan Etos Kerja Islami Terhadap Kinerja Karyawan Pada Bank Syariah Mandiri Cabang Cirebon. FSEI IAIN Syekh Nurjati Cirebon, 23(45), 5-24.

Prasetyowati, Y. T. (2011). Pengaruh Disiplin, Lingkungan Kerja, Budaya Kerja, Motovasi dan Kepemimpinan Terhadap Kinerja Karyawan PT Karavan di Surakarta. Universitas Muhammadiyah Surakarta, 53(9), 287.

Sakban, Nurmal, I., \& Ridwan, R. (2019). Manajemen Sumber Daya Manusia. Journal Od Administration and Educatuonal Management, 2(1), 1-21.

Sari, D. M. (2017). Pengaruh Etika Kerja Islam, Motivasi Kerja Islam Dan Lingkungan Kerja Islam Terhadap Kinerja Karyawan (Studi Kasus Pada Karyawan Bank BRI Syariah Kantor Cabang Jakarta BSD). Universitas Islam Negeri Syarif Hidayatullah Jakarta. http://www.albayan.ae

Sugiyono. Statistik Untuk Penelitian. 2008. Alfabeta : Bandung. 